\title{
Analysis Feasibility Level of Practical Guidance Semiriset Based Guided Inquiry on BSNP for Senior High School
}

\author{
Fridawati Siburian \\ Postgraduate Student \\ State University of Medan \\ Medan, Indonesia \\ fridasiburian88@gmail.com
}

\author{
Iis Siti Jahro \\ Postgraduate Student \\ State University of Medan \\ Medan, Indonesia
}

\author{
Retno Dwi Suyanti \\ Postgraduate Student \\ State University Of Medan \\ Medan, Indonesia
}

\begin{abstract}
This type of research is research and development $(R \& D)$. The purpose of this study is determine the level of feasibility of practical guidance semiriset based guided inquiry on BSNP for Senior High School. This research was a descriptive analysis study. The sample are 3 lecturer of chemistry and 20 teachers of chemistry. The Instrument used BSNP questionnaire. The results of the study show that (1) aspect of feasibility the content in practical guidance semiriset based guided inquiry have an average of 4,61 and used school subject have an average of 3,14 (2) The aspect feasibility of language in practical guidance semiriset based guided inquiry have an average of 4,63 and used school subject average of 3,03 (3) The aspect feasibility of presentation in practical guidance semiriset based guided inquiry have an average of 4,63 and used school subject have an average of 3,21 (4) The aspect feasibility of graphing in practical guidance semiriset based guided inquiry have an average of 4,62 and used school subject have an average of 3,09 . Based on the aspect of feasibility the content, language, presentation, and graphing in practical guidance semiriset based guided inquiry on BSNP for Senior High School and used school subject have an average of 4.62 (valid that meaning decent and doesn't need revision) and 3,12 (valid that meaning sufficient and doesn't need revision (sufficient)).
\end{abstract}

Keywords-Analysis; Practical guide book; Questionnaire.

\section{INTRODUCTION}

The main purpose of science education is to help students become scientific and educated (Turkmen \& Usta, 2007). Education is intended to humanize humans. Through education, the realm and objectives of national ideals will be achieved so that intellectuals are born who uphold the truth and live noble morals and morals. In order to achieve these objectives, several components of cooperation are needed. Among other things to create competent human qualities so as to be able to compete in the eyes of the world. The component includes facilities and completeness of learning in schools.

Derlina (2013) states that the low level of thinking ability of students can be caused by learning activities carried out by the teacher does not facilitate students to practice developing their formal thinking skills. Based on observations through the CFIT test (Cultural Fair Intelligence Test) in several schools, data were obtained that there were still many students who had not reached the stage of formal thinking in high school. Science learning seems boring because it is partly abstract in nature which makes it difficult for students to understand the science lesson. These problems can be overcome by pleasant learning and include the activity of students in learning, one of which is by doing practical activities. Most students' knowledge is built by conducting experiments / research in the laboratory. Educational institutions in America recommend that learning time should be emphasized in laboratory activities (Campbell \& Bohn, 2008).

Practical activities can provide opportunities for children to practice reasoning skills, the ability to think rationally, apply scientific attitudes and methods to find truth rather than what they learn (Hofstein, 2004; Jahro, 2009; Kurniati, 2011). The right practicum activity will play an effective role in honing cognitive, metacognitive, ability to do practicum and students' interest in chemistry lessons. Laboratory activities are carried out through practical methods, namely methods that involve students directly by doing it themselves, following a process, observing an object, analyzing, proving and drawing conclusions themselves. Demircioğlu \& Yadigaroğlu (2011) suggested that practicum methods are more effective in gaining student understanding because they have a lot of experience in measuring, interpreting, drawing conclusions and making generalizations. Azhar (2016) in his research showed that giving students the opportunity to conduct experiments had a huge influence in the learning process.

\section{LITERATURE}

\section{A. Research And Development}

According to Borg \& Gall (1989) development research is a process used to develop and validate educational products. This step of research or development process consists of a study of product research findings that will be 
developed, developing products based on these findings, conducting field trials according to the background in which the product will be used, and revising the results of field tests.

\section{B. Practicum in Chemical Learning Process}

The laboratory approach in teaching was motivated by Pestalozzi who argued that education must take place by doing as a substitute for the words learning methods must be analytical, real objects, and initiatives (ideas) must precede symbols and words (Hamalik, 1994). Good learning achievement will be obtained if students are able to manifest the knowledge gained by direct observation and experience (Dale, 1969).

\section{Practical Guidance Semiriset}

Semiriset practicum guide in this research is a practical guide which is compiled by adopting the existing practical guide from the available guidebook. The practical guide is emphasized more on efforts to improve science process skills through more detailed work procedures, containing questions that encourage student curiosity and improve problem solving skills.

\section{Inquiry Learning}

The National Research Council (2000) defines inquiry as follows: Inquiry is a multi-faceted activity that includes observation, making questions, examining books or other sources of information to see what has been known, planning investigations, re-examining what is known according to experimental evidence, using tools to collect, analyze and interpret data, submit answers, explanations and predictions, and communicate results. Syntax or overall pattern in Guided Inquiry. According to Shah (2004) in applying the Guided Inquiry method in the classroom, there are several procedures that must be implemented in teaching and learning activities in general as follows : Stimulation, Problem statement, Data collection ,Data processing, Verification and Generalization.

\section{E. Science Process Skills}

According to Karsli \& inahin (2009) science process skills are basic facilities that help students to be active and learning is experienced directly. Dahar (2011) says that science process skills are the ability of students to apply scientific methods in understanding, developing and discovering science.

According to Warianto (2011) science skill indicators consist of eleven indicators equipped with subindicators, among others : Observing, grouping, interpreting, predicting, asking questions, hypothesizing, planning experiments, using tools / materials, applying concepts, and communicating.

\section{F. Problem solving skill}

According to Gagne (1970) problem solving skills are a form of skill that requires thinking by using and connecting with various rules that we already know according to different combinations. Likewise in learning, students will find various kinds of problems, where in order to be able to solve the problems they face they certainly need a process that must be passed. Problem solving can occur suddenly when the problem becomes a light for someone called insigth

\section{RESEARCH METHOD}

This research uses research and development (R \& D) method.The population in this study were all high school chemistry teachers and all XI IPA students in Brigadier General Katamso I Medan High School 2018/2019 and used the revised 2013 curriculum. Sampling is done by purposive sampling technique so that the experimental class is obtained. Validator in this study was a lecturer in Unimed chemistry and chemistry teacher who was selected by purposive sampling. (1) The selected lecturers are 3 people with minimum education criteria for S2, currently actively teaching and mastering Basic Chemistry material relevant to high school material. (2) Chemistry teachers as many as 20 people who have academic education. The design of this st Determination of Practical Guide liagram in Figure 3.1.
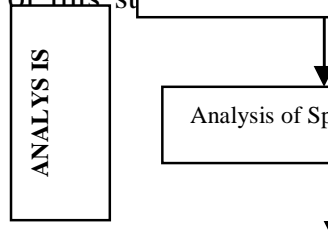

Analysis of Specified Practical Guides
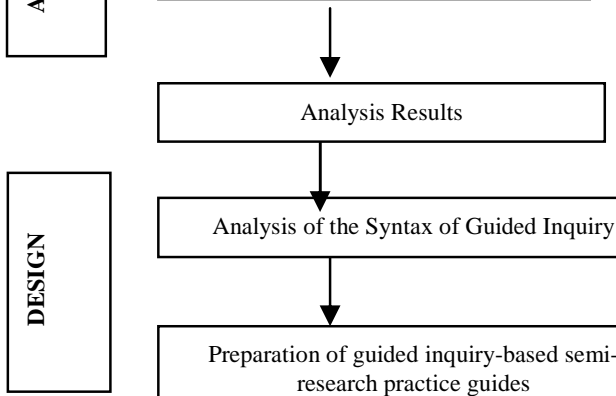

Analysis of the Syntax of Guided Inquiry
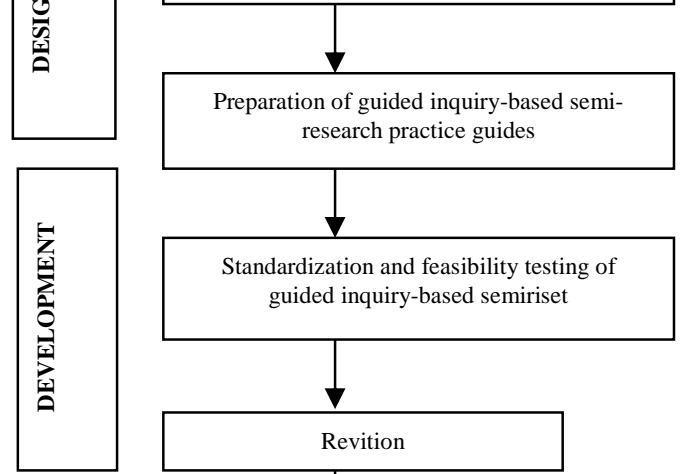
research practice guide
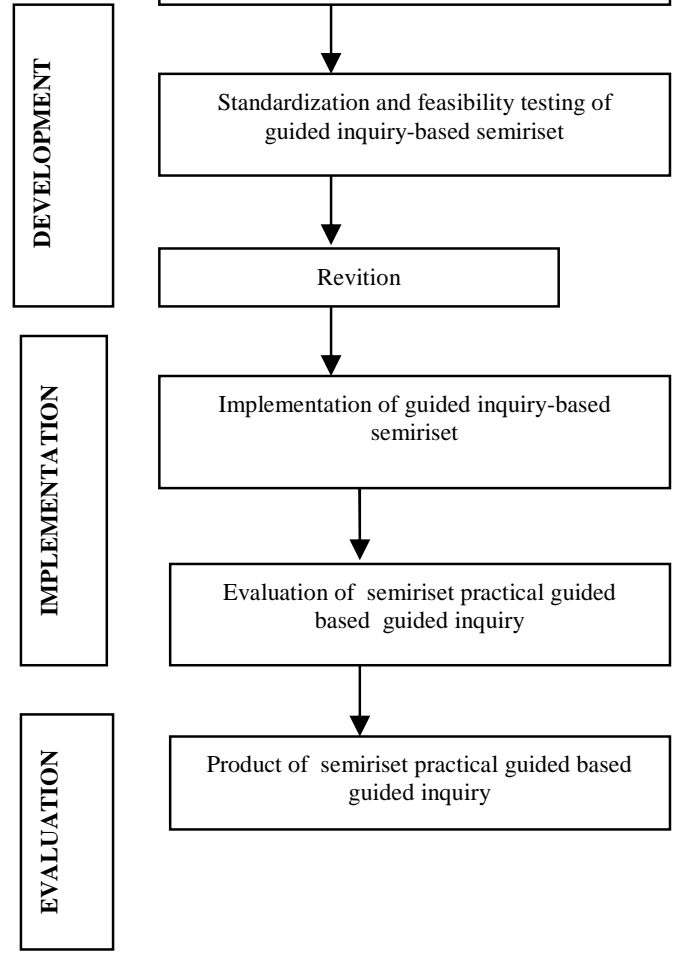
Fig. 1 Flow of Development of Semiriset Practical Guides

\section{RESULT AND DISCUSSION}

This research was conducted on a practical guide used by schools and practical guidance semiriset based guided inquiry. Feasibility analysis is carried out on aspects of content, language, presentation and graphics.

\section{A. Aspect of Feasibility Content}

In the aspect of feasibility content, there are 11 components related to it, among others: (1) practicum suitability, (2) practicum objectives, (3) work harmony (4) material coverage, (5) experimental tools, (6) experimental material, (7) work procedures, (8) observation tables, (9)

discussion of observations (10) conclusions and (11) questions.

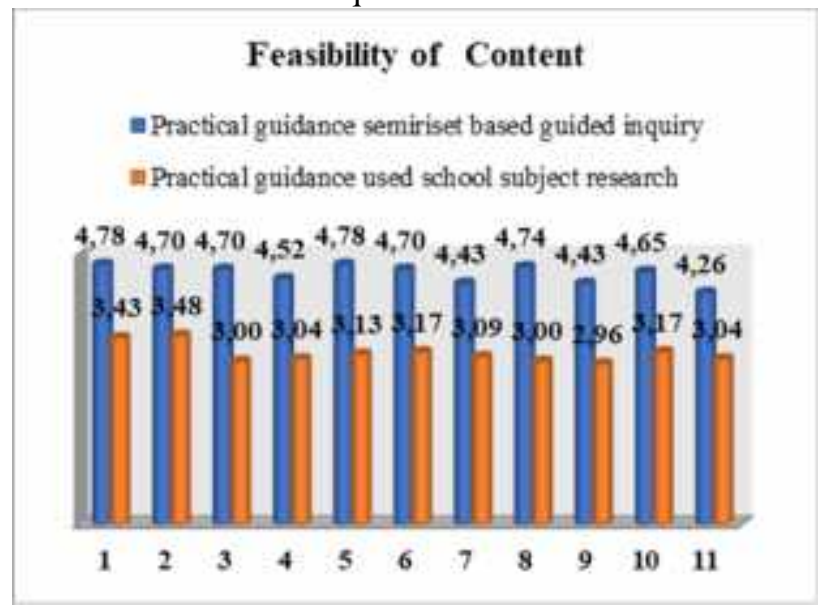

Fig.2. The Feasibility in Practical Guidance Semiriset Based Guided Inquiry and Practical Guidance Used School Research is Based on the Aspect of Feasibility Content.

\section{B. Aspect of Feasibility Language}

In terms of language feasibility, there are five components related to it, among others: (1) according to student development, (2) communicative, (3) conformity with correct Indonesian rules, (4) and symbols.

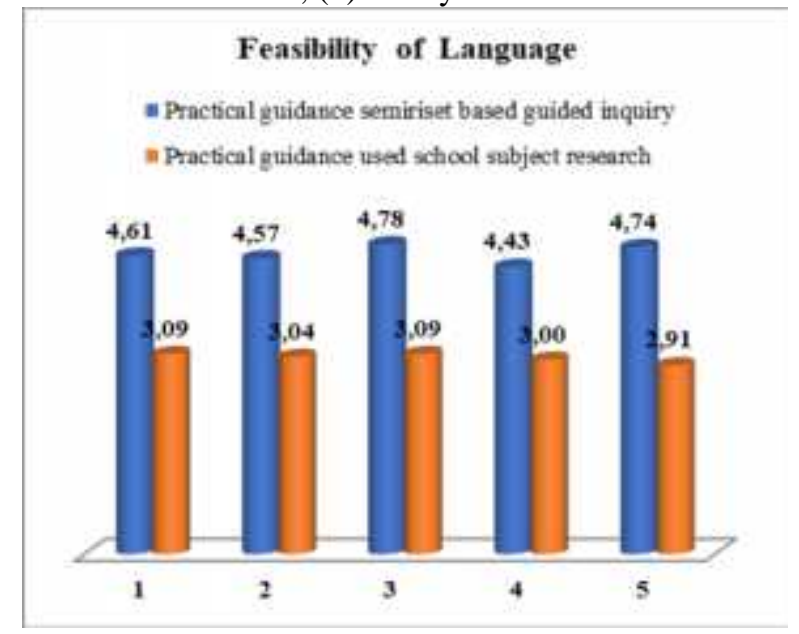

Fig.3. The Feasibility in Practical Guidance Semiriset Based Guided Inquiry and Practical Guidance Used School Research is Based on the Aspect of Feasibility Language.

\section{Aspect of Feasibility Presentation}

In the aspect of presentation feasibility, there are 4 components related to it, among others: (1) systematic consistency of the presentation in each experiment, (2) bibliography, (3) general guidelines in the laboratory (4) Glossary.

\section{Feasibility of Presentation}

mPractical guidance semiriset based guided inquiry

= Practical guidance used school subject reseanch

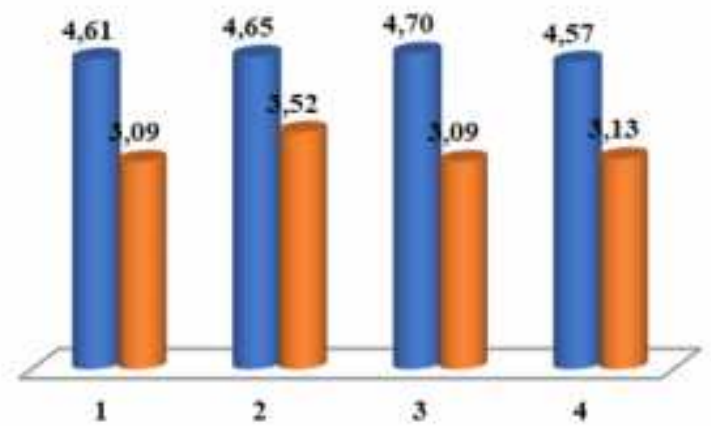

Fig. 4 The Feasibility in Practical Guidance Semiriset based Guided Inquiry and Practical Guidance Used School Research is Based on the Aspect of Feasibility Presentation.

\section{Aspect of Feasibility Graphing}

In the aspect of feasibility of graphics, there are 3 components related to it, among others: (1) the size of a practical guide book, (2) skin typography practical guide book (3) typography of the contents of the practical guidebook.

\section{Feasibility of Graphing}

=Practical guidance semiriset based guided inquiry

= Practical guidance used school subject research

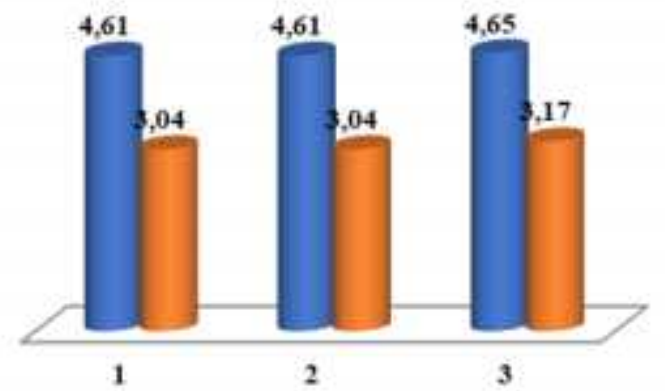

Fig. 5. The Feasibility in Practical Guidance Semiriset Based Guided Inquiry and Practical Guidance Used School Research is Based on the Aspect of Feasibility Graphing. 


\section{CONCLUSION}

Based aspect of feasibility the content in practical guidance semiriset based guided inquiry have an average of 4,61 and used school subject have an average of 3,14 (2) The aspect feasibility of language in practical guidance semiriset based guided inquiry have an average of 4,63 and used school subject average of 3,03 (3) The aspect feasibility of presentation in practical guidance semiriset based guided inquiry have an average of 4,63 and used school subject have an average of 3,21 (4) The aspect feasibility of graphing in practical guidance semiriset based guided inquiry have an average of 4,62 and used school subject have an average of 3,09 .

Based on the aspect of feasibility the content, language, presentation, and graphing in practical guidance semiriset based guided inquiry on BSNP for Senior High School and used school subject have an average of 4.62 (valid that meaning decent and doesn't need revision) and 3,12 (valid that meaning sufficient and doesn't need revision (sufficient)).

\section{Acknowledgment}

This research was supported by thesis supervisor Dr. Iis Siti Jahro, M.Si. And Prof. Dr. Ir. Retno Dwi Suyanti, M.Si that have given the suggestion in order to complete this research.

\section{References}

[1] Azhar, R. (2016). Pengembangan Penuntun Praktikum Kimia SMA Kelas XI Berbasis KPS Pada Materi Hidrolisis Garam Terintegrasi Pendidikan Karakter. Tesis. Pascasarjana Universitas Negeri Medan.

[2] Borg, W.R., \& Gall, M.G. (1989). Educational Research: An Introduction $\left(5^{\text {th }}\right.$ ed $)$. New York: Longman.

[3] Budiningsih, Asri (2005). Belajar dan Pembelajaran. Jakarta: PT. Rineka Cipta.

[4] Chambliss, M. J., \& Calfee, R. C. (1989). Designing science textbook to enhance student understanding. Educational Psychologist, 24 (3), $307-$ 322

[5] Chatterjee, S., Williamson, V. M., McCann, K., \& Peck, M. L. (2009). Surveying students' attitudes and perceptions toward guided-inquiry and open-inquiry laboratories. Journal of Chemical Education, 86(12), 1427.

[6] Campbell, T., \& Bohn, C. (2008). Science laboratory experiences of high school students across one state in the US: descriptive research from the classroom. Science Educator, 17(1), 36

[7] Chang, H. Y., Hsu, Y. S., Wu, H. K., \& Chen, C. M. (2014). Path analyses of how students develop conceptual knowledge and inquiry skills in a simulation-based inquiry environment. In 22nd International Conference on Computers in Education, ICCE 2014. Asia-Pacific Society for Computers in Education.

[8] Dahar, R.W., (2001). Teori-Teori Belajar dan Pembelajaran. Jakarta: Erlangga.

[9] Dale, E., (1969), Audiovisual Methods in Teaching, $3^{\text {rd }}$ edition, The Dryden Press, New York

[10] Dalyono. (1996). Psikologi Pendidikan. Jakarta: PT. Rineka Cipta.

[11] De Bono, E. (2007). Revolusi Berpikir. Bandung; PT. Mizan Pustaka

[12] Deli, A. C. (2017). Pengembangan Penuntun Praktikum Inovatif Terintegrasi Model Pembelajaran Inkuiri Terbimbing Pada Materi Reaksi Redoks Terhadap Hasil Belajar Kognitif Dan Keterampilan Siswa Kelas X SMA. Tesis. Pascasarjana Universitas Negeri Medan.

[13] Demircioğlu, G., \& Yadigaroğlu, M. (2011). The Effect of Laboratory Method on High School Students Understanding of the Reaction Rate.
[14] Derlina., (2013). Pengembangan Perangkat Pembelajaran Fisika Berbasis Model Pembelajaran Konstruktivis Untuk Meningkatkan Kemampuan Berpikir Logis Siswa SMA, Prosiding Seminar Hasi Penelitian Lembaga Penelitian Unimed Tahun 2013 Bidang Pendidikan

[15] Dihanti, E. (2013). Contextual Teaching and Learning (CTL); Sebagai Strategi dan Model Pembelajaran. Makalah Terbuka dalam Latihan PTK PGRI Kota Depok di Graha Insan Cita Kota Depok, 7.

[16] Emiliya, R. (2015). Pengembangan Penuntun Praktikum Mode Discovery dan Project Based Learning Pada Pembelajaran Asam Dan Basa di SMA Kelas XI. Tesis. Pascasarjana Universitas Negeri Medan.

[17] Fakayode, S.O. (2014). Guided-Inkuiri Laboratory Experiments in The Analytical Chemistry Laboratory Curriculum. Analytical and Bioanalytical Chemistry, 406 (5), 1267-1271.

[18] Faizi, M., (2013). Ragam Metode Mengajarkan Eksakta pada Murid, Diya Press, Yogyakarta

[19] Gupta, T., Burke, K. A., Mehta, A., \& Greenbowe, T. J. (2014). Impact of guided-inquiry-based instruction with a writing and reflection emphasis on chemistry students' critical thinking abilities. Journal of Chemical Education, 92(1), 32-38.

[20] Hamalik, O. (1994). Media Pendidikan, Bandung: PT. Citra Aditya Bakti.

[21] Hanum, A. Y. (2014). Pengembangan Penuntun Praktikum Kimia Inovatif Untuk SMA/MA Kelas XII Sesuai Kurikulum 2013. Tesis. Pascasarjana Universitas Negeri Medan.

[22] Hofstein, A. (2004). The laboratory in chemistry education: Thirty years of experience with developments, implementation, and research. Chemistry education research and practice, 5(3), 247-264.

[23] Jahro, I. S. (2009). Desain Praktikum Alternatif Sederhana (PAS) Wujud Kreativitas Dalam Pelaksanaan Kegiatan Praktikum Pada Pembelajaran Kimia. 44-47.

[24] Karsli, F., \& Şahin, Ç. (2009, June). Developing worksheet based on science process skills: Factors affecting solubility. In Asia-Pacific Forum on Science Learning and Teaching (Vol. 10, No. 1, pp. 1-12). The Education University of Hong Kong.

[25] Kimberlin, S., \& Yezierski, E. (2016). Efectiveness of Inquiry-Based Lessons Using Particulate Level Models To Develop HIGH School Student's Understanding of Conceptual Stoichiometry. Journal of Chemical Education, 93 (6), 1002-1009.

[26] Kurniati dan Wahyuningrum, D., (2011), Pengembangan Pembelajaran Inkuiri Terbimbing di SMA/MA melalui Penyusunan Modul Praktikum Isolasi dan Identifikasi Senyawa dalam Daun Tanaman Mint (Mentha cordifolia opiz), Prosiding Simposium Nasional Inovasi Pembelajaran dan Sains 2011, Institut Teknologi Bandung, 1-5

[27] Marpaung, M. E. (2017). Pengembangan Penuntun Praktikum Stoikiometri Inovatif Sesuai Kurikulum 2013 Berbasis Keterampilan Proses Sains. Tesis. Pascasarjana Universitas Negeri Medan.

[28] Miftah, M. (2013). Pengembangan Perangkat Pembelajaran Berorientas Metode Penemuan Terbimbing dalam Pencapaian Keterampilan Proses Sains dan Keterampilan Berpikir Kritis Peserta Didik MAN 2 Model Makassar. Jurnal Pendidikan Fisika Tadulako Online (JPFT), 4(1)

[29] Mutrovina, N. (2015). Meningkatkan Keterampilan Proses Sains Siswa Melalui Penerapan Model Pembelajaran Inkuiri Terbimbing Pada Mater Reaksi Reduksi-Oksidasi di Kelas X SMA Negeri 12 Surabaya (Increasing The Student Science Prosess Skills With Guided Inquiry Learning Model At Reduktion-Oxidation Reaction For X Grade Of 12 Surabaya Senior High School). UNESA Journal of Chemical Education, 4(3).

[30] Mulyasa, E. (2006). Menjadi guru profesional menciptakan pembelajaran kreatif dan menyenangkan. Bandung: Remaja Rosdakarya.

[31] National Research Council. (2000). Inquiry and the national science education standards; A guided for teaching and learning. National Academies Press.

[32] Nasution, H. A. (2016). Pengembangan Penuntun Praktikum Kimia Dengan Menggunakan Model Inkuiri Dan Project Based Learning Pada Materi Sistem Periodik Unsur. Tesis. Pascasarjana Universitas Negeri Medan. 
[33] Nazarova, T.S., \& Gosporadik, I. P. (2006). Strategy for the Development of the Textbook. Russian Education \& Society, 46 (6), 86102.

[34] Nejla Gultepe, (2016). High school Science Teacher's Views on Science Process Skill. International Journal of Environmental \& Science Education Vol.11 No.5. Dumlupinar University, Turkey.

[35] Nugraha, W.A., (2006), Penerapan Model Praktikum Semi Riset Pada Praktikum Kimia Fisika 2, Laporan Hasil penelitian, Jurusan Kimia FMIPA Universitas Negeri Medan

[36] Nuryani, R. (2005). Strategi belajar mengajar biologi. Malang: IKIP.

[37] Ottander, C., \& Grelsson, G. (2006). Laboratory work; the teachers' perspective. Journal of Biological Education, 40 (3), 113-118.

[38] Padmo, D., (2014), Teknologi Pembelajaran: Peningkatan Kualitas Belajar Melalui Teknologi Pembelajaran, Pusat Teknologi Komunikasi dan Informasi Pendidikan, Jakarta

[39] Pasaribu, B. S. (2016). Analisis dan Pembangan Penuntun Praktikum Inovatif yang Terintegrasi Berbasis Proyek dan Inquiry untuk SMA Kelas XI Semester I Materi Hidrokarbon Sesuai Kurikulum 2013. Tesis. Pascasarjana Universitas Negeri Medan.

[40] Putra, H. E. (2016). Pengembangan Penuntun Praktikum Interaktif pada Materi Hidrokarbon dan Minyak Bumi di SMA/MA (Doctoral dissertation, UNIMED).

[41] Rahmiyati, S. (2008). Keefektifan Pemanfaatan Laboratorium di Madrasah Aliyah Yogyakarta. Jurnal Penelitian dan Evaluasi Pendidikan, 11 (1).

[42] Rosmalinda, D., Rusdi, M., \& Hariyadi, B. (2013). Pengembangan Modul Praktikum Kimia SMA Berbasis PBL (Problem Based Learning). Edu-Sains: Jurnal Pendidikan Matematika dan Ilmu Pengetahuan Alam Universitas Jember, 2(2).

[43] Turkmen, H., \& Usta, E. (2007). The Role of Learning Cycle Approach Overcoming Misconceptions in Science. Kastamonu Education Journal, 15(2), 491-500

[44] Tresnaningsih, R. (2012). Pembelajaran Aktif Untuk Meningkatkan Kemampuan Berpikir Tingkat Tinggi Melalui Keterampilan Menyelesaikan Masalah Pada Perkuliahan Kalkulus Lanjut. JIPM (Jurnal Ilmiah Pendidikan Matematika), 1(1).

[45] Tresnawati, R dan Dwiyanti, G., (2013), Pengembangan Prosedur Praktikum Kimia SMA Pada Topik Larutan Elektrolit Dan Nonelektrolit, Jurnal Riset Dan Praktik Pendidikan Kimia, Vol.1, No 1

[46] Qing, Z., Jing, G., \& Yan, W. (2010). Promoting Preservice Teachers' Critical Thinking Skills by Inquiry-Based Chemical Experiment. Procedia-Social and Behavioral Sciences, 2(2), 4597-4603.

[47] Sanjaya, W., (2010). Strategi Pembelajaran Berorientasi Standar Proses Pendidikan, Jakarta: Kencana Prenada Media Group.

[48] Saptorini, (2008). Peningkatan Keterampilan Generik Sains Bagi Mahasiswa Melalui Praktikum Kimia Analisis Instrumen Berbasis Inkuiri, Jurnal Inovasi Pendidikan Kimia, 2(1): 190-198

[49] Selvianti, R. Jusniar. (2013). Efektivitas Metode Pemecahan Masalah untuk Meningkatkan Hasil Belajar dan Keterampilan Generik Sains Siswa Kelas XI IPA 2 SMA Negeri 8 Makassar (Studi Pada Materi Pokok Hidrolisis Garam). Jurnal Chemica, 14(1), 55-65.
[50] Setyosari, H. P. (2016). Metode Penelitian Pendidikan \& Pengembangan. Prenada Media.

[51] Silaban R., (2016). Desain Pembelajaran Kimia Melalui Kegiatan Praktikum Semi Riset. Program Pascasarjana. UNIMED.

[52] Situmorang, M., \& Saragih, N. (2013). Pengembangan Modul Pembelajaran Kimia SMA Melalui Inovasi Dan Integrasi Pendidikan Karakter Untuk Mempersiapkan Sumberdaya Berkarakter Menghadapi Persaingan Global. Jurnal Sistem Informasi Penelitian Pendidikan Pusat Penelitian Kebijakan, 1-17.

[53] Smith, K. C. \& Garza, A. (2015). Using Conductivity Measurements to Determine the Identities and Concentrations of Unknowns Acids: An Inquiry Laboratory Experiment. J. Chem. Educ, 9

[54] Sudjana, (2005), Metoda Statistika, Tarsito, Bandung

[55] Sugiyono, (2010), Metode Penelitian Pendidikan (Pendekatan Kuantitatif, Kualitatif, dan $R \& D)$, Alfabeta, Bandung

[56] Susiwi, (2007), Handout: Belajar dan Pembelajaran Kimia UPI

[57] Sutiadi, A. (2013). Bahan Ajar Workshop Penyusunan Instrumen Soal Kognitif dan Keterampilan Proses Sains.

[58] Suyanti, R. D. (2010). Strategi Pembelajaran Kimia. Yogyakarta: Graha Ilmu.

[59] Syah, M. (2004). Psikologi Pendidikan. Bandung: PT. Grafindo Persada.

[60] Tambunan, M., (2011), Strategi Belajar dan Mengajar Pembelajaran Kimia, FMIPA UNIMED, Medan

[61] Tawil, Muh dan Liliasari. (2013). Berpikir Kompleks, Badan Penerbit UNM, Makassar.

[62] Tawil, Muh dan Liliasari. (2014). Keterampilan-Keterampilan Sains dan Implementasinya Dalam Pembelajaran IPA, Badan Penerbit UNM Makassar.

[63] Tim Penyusun, (2016), Panduan Penulisan Penuntun Praktikum dan Laporan Praktikum Diambil Prari http://d3ak.staff.uii.ac.id/files/2016/03/panduan-penulisan-penuntunpraktikum-dan-laporan.pdf

[64] Tüysüz, C. (2010). The Effect of the Virtual Laboratory on Students' Achievement and Attitude in Chemistry. International Online Journal of Educational Sciences, 2(1).

[65] Weaver, Marisa dkk. (2016). Developing Students' Critical Thinking, Problem Solving, and Analysis Skills in an Inquiry-Based Synthetic Organic Laboratory Course, J. Chem. Education.

[66] Wiyanto, (2005), Pengembangan Kompetensi Dasar Bersikap Ilmiah Melalui Kegiatan Laboratorium bErbasis Inkuiri bagi Siswa SMA, Jurnal Pendidikan Fisika Indonesia, 3(3): 167-172

[67] Yani, A. F. S. (2015). Pengembangan Penuntun Praktikum Kimia SMA Kelas XI Pada Materi Hidrolisis Garam Sesuai Model Pembelajaran Penemuan dan Berbasis Proyek. Tesis. Pascasarjana Universitas Negeri Medan.

[68] Zakiah, (2015). Pengembangan Penuntun Praktikum Model Discovery Dan Project Based Learning Pada Pembelajaran larutan elektrolit dan nonelektrolit Di SMA. Tesis. Pascasarjana Universitas Negeri Medan. 